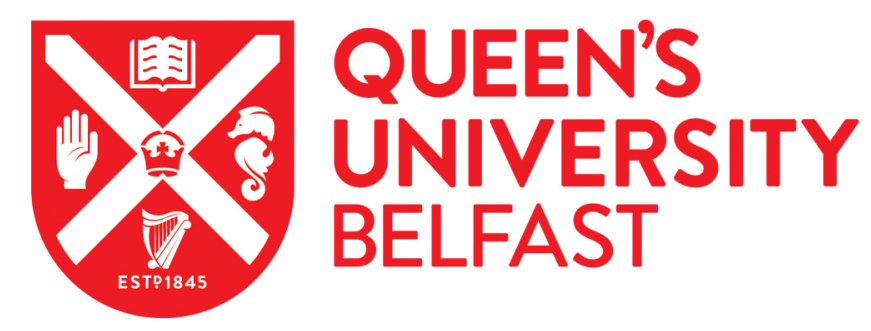

\title{
The Influence of Religion and Ethnonationalism on Public Attitudes towards Amnesty: Northern Ireland as a Case Study
}

Brewer, J. D., \& Hayes, B. C. (2016). The Influence of Religion and Ethnonationalism on Public Attitudes towards Amnesty: Northern Ireland as a Case Study. Nationalism and Ethnic Politics, 22(4), 393-411. https://doi.org/10.1080/13537113.2016.1239444

Published in:

Nationalism and Ethnic Politics

Document Version:

Peer reviewed version

Queen's University Belfast - Research Portal:

Link to publication record in Queen's University Belfast Research Portal

Publisher rights

Copyright 2016 Taylor \& Francis Group, LLC

This is an Accepted Manuscript of an article published by Taylor \& Francis in Nationalism and Ethnic Politics on 02 Nov 2016, available online: http://www.tandfonline.com/doi/full/10.1080/13537113.2016.1239444

\section{General rights}

Copyright for the publications made accessible via the Queen's University Belfast Research Portal is retained by the author(s) and / or other copyright owners and it is a condition of accessing these publications that users recognise and abide by the legal requirements associated with these rights.

Take down policy

The Research Portal is Queen's institutional repository that provides access to Queen's research output. Every effort has been made to ensure that content in the Research Portal does not infringe any person's rights, or applicable UK laws. If you discover content in the Research Portal that you believe breaches copyright or violates any law, please contact openaccess@qub.ac.uk. 


\title{
The Influence of Religion and Ethnonationalism on Public Attitudes Towards Amnesty: Northern Ireland as a Case Study
}

\author{
JOHN D. BREWER \\ Queen’s University Belfast \\ and \\ BERNADETTE C. HAYES \\ University of Aberdeen
}

The granting of amnesties has now become a cornerstone of peacebuilding efforts in societies emerging from conflict. Yet, the impact of the role of religion and ethnicity in determining attitudes towards such arrangements has not been empirically assessed. Mindful of this omission, this article investigates the relationship between a range of religious measures - religious practices and beliefs in and about God - and ethnonationalist identity on public attitudes toward amnesty in Northern Ireland. Based on nationally representative survey data, the results suggest that although Protestants are significantly more opposed to such an initiative than Catholics, both religious beliefs and ethnonational identity are significant, albeit divergent, net predictors with respect to their differing views.

Address correspondence to Bernadette C. Hayes, Institute for Conflict, Transition, and Peace Research, School of Social Science, University of Aberdeen, Aberdeen AB24 3QY, Scotland, UK. E-mail: b.hayes@abdn.ac.uk 


\section{INTRODUCTION}

The post-cold war era has witnessed a proliferation of intrastate conflicts based on ethnic differences. Intrastate conflicts, or civil wars, have now replaced interstate conflicts, or international wars, as the most prevalent forms of violence. ${ }^{1}$ Currently, around 95 per cent of wars are civil wars, the large majority of which are considered ethnic conflicts, although what exactly constitutes an ethnic conflict is open to much dispute. ${ }^{2}$ Moreover, as Collier et al point out, ${ }^{3}$ once they break out, civil wars are difficult to stop: about half of the countries emerging from civil war slip back into violence within five years, and this pattern is particularly marked when the antagonists are mobilized along ethnic lines. ${ }^{4}$ It is important to note, however, ethnic conflicts are not a new phenomenon. Throughout history, ethnic wars have been a common form of armed conflicts around the world. Even today, within-country conflicts based on ethnic divisions are considered one of the most pervasive and deadly forms of war. While there is evidence to suggest that the number of such conflicts have declined considerably in recent years - most notably since their earlier peak in the mid-1990s ${ }^{5}$ - ethnic conflict is still considered one of the greatest threats to international security in the world today. ${ }^{6}$

While much has been written on the nature, extent and causes of ethnic conflict, its relationship to religion remains relatively unexplored. As a number of scholars have noted, classic studies of ethnicity, ethno-nationalism and ethnic conflict have paid little attention to religion, viewing it as either irrelevant or marginal at best. ${ }^{7}$ Pointing instead to the role of a range of economic and/or political influences such as ethnic grievances and fractionalisation, greed, relative deprivation and repression, the political organisations of minority groups and their desire for selfdetermination - traditional studies of ethnic conflict suggest that it is these factors, and not religion, which are the primary, if not sole, determinants of ethnic rebellion and conflict. ${ }^{8}$ Yet, the absence of such attention as to the role of religion must be considered surprising for the following reasons.

First, not only do many ethnic conflicts have a strong religious dimension but religion and ethnicity as a source of identity are often deeply intertwined. In fact, not only is religion often included in definitions of ethnicity but most conflict analysts treat religion as a subset of ethnicity. ${ }^{9}$ Second, contrary to the views of secularisation 
theorists that religion would either wither away or retreat to the private sphere as a result of modernisation, ${ }^{10}$ there is evidence to suggest that not only have religious conflicts significantly increased more than nonreligious conflicts, particularly since the 1980s, but conflicts involving religious factors are more intense and intractable in nature. ${ }^{11}$ In fact, some scholars argue that not only has modernity and its accompanying insecurity led to the revival of religion but that religiously motivated violence has now become an ubiquitous element of modern conflicts and the dominant form of terrorism in the world today. ${ }^{12}$

While more recent research has focused on the relationship between religion and ethnic conflict, the relationship between religion, ethnicity and transitional justice mechanisms has remained largely unexplored. This is particularly the case when we consider the influence of ethnonationalism and religious conviction on attitudes towards amnesty. The absence of such research may be considered surprising for many reasons. First, amnesties have become a central feature of transitional justice efforts in societies emerging from conflict. In fact, the granting of amnesties has now moved centre stage as the most frequently used transitional justice mechanism for societies emerging from conflict. ${ }^{13}$ Secondly, in addition to political elites, many of whom had been involved in the conflict that preceded the political settlement, religious leaders have also been actively engaged in the establishment and delivery of such transitional justice mechanisms. As a number of scholars point out, not only have religious personnel played a crucial role in mediating between political elites and the mass public in establishing post-conflict peace agreements, they have also been key players in the design and delivery of transitional justice mechanisms, such as truth commissions and the granting of amnesties. ${ }^{14}$ In fact, at least as far as the South Africa is concerned, some scholars go so far as to suggest that the involvement of religious leaders in the Truth and Reconciliation Commission (TRC) and the inclusion of a religious discourse was both a vital and necessary step in facilitating its political stability and transition to a sustainable and peaceful democracy. ${ }^{15}$

In summary, views on the role of religion and ethnicity in relation to both conflict generation and prevention remain highly contested. While some scholars point to the over-arching effects of ethnicity, viewing religion as marginal at best, others point to the primacy of religion as both a source of conflict and of 
reconciliation within society. It is with these competing views in mind that this article focuses on the role of religion and ethnonational identity in determining public attitudes towards amnesty in Northern Ireland. The article proceeds in two stages. First, it outlines previous research on the role of religion and ethnicity in relation to the conflict in Northern Ireland. Secondly, building on this analytical discussion and using data from the 2011 Northern Ireland Social and Political Attitudes Survey, it examines the impact of religion and ethnonational identity on public attitudes towards amnesty. The use of Northern Ireland as a case study may be considered particularly appropriate for the following three reasons.

First, the Northern Ireland peace accord is now considered an exemplar of conflict resolution throughout the world. Indeed, since its ratification in 1998, a virtual cottage industry has emerged which seeks to export the Northern Ireland experience as a model for resolving ethnic and/or religious conflict around the globe. Secondly, of the various measures introduced to deal with the legacy of Northern Ireland's violent past the early release of prisoners emerged as one of the most unpalatable elements in the Agreement. Although the peace accord did not propose a general amnesty, ${ }^{16}$ the vast majority of people, particularly within the unionist community, found this aspect of the Agreement repugnant. ${ }^{17}$ These deep-seated divisions re-emerged when later recommendations such as the suggested one-off recognition payment for the nearest relative of those who died, ${ }^{18}$ or a 'limited' amnesty for perpetrators involved in Troubles-related deaths ${ }^{19}$ were proposed. While members of the Protestant community reacted in horror to these suggestions, the Catholic community was somewhat more accepting in their views, seeing it as a necessary, albeit distasteful, price for dealing with the legacy of Northern Ireland's violent past. ${ }^{20}$ Thirdly, unlike many other Western post-industrial nations, Northern Ireland remains a deeply religious society. Currently, 89 per cent of the adult population self-identify with a religious affiliation. It is important to note, moreover, that this religious identification is more than merely nominal: Northern Ireland has traditionally manifested one of the highest levels of religious observance found in Europe. $^{21}$ 


\section{RELIGION, ETHNICITY AND THE NORTHERN IRELAND CONFLICT}

Academic opinion remains sharply divided in terms of the role that religion has played in the Northern Ireland conflict. On the one hand, there are those who argue that religion has not played a significant role in the conflict and is thus irrelevant as a solution. As McGarry and O’Leary, one of the main proponents of this position, concluded: 'Explanations that emphasise the primacy of religion...need to be exposed to strong light. When that happens, they evaporate, leaving little residue. ${ }^{22}$ According to this approach the conflict is not religious but rather ethnonationalist in nature and thus must be understood primarily as a clash about ethnic identity and contested national territory; Unionists who claim a British identity and wish to maintain the link with Britain versus Nationalist who claim an Irish identity and want an united Ireland. Or, as McGarry and O’Leary, put it when explaining the Northern Ireland conflict: [it] is fundamentally rooted in ethno-national antagonism. ${ }^{23}$ Thus, from this perspective, religion is not the source of the conflict but should be seen simply as an 'ethnic marker'. As such, the terms Protestant and Catholic should be considered nothing more than badges of identity that simply distinguish nationalists and unionists; a view it should be noted that not only found favour among leaders of the four main churches at the onset of the conflict ${ }^{24}$ but was subsequently widely endorsed by the British and Irish government and underpins the Northern Ireland peace accord - Belfast/Good Friday Agreement - which was ratified in 1998.

On the other hand, there are a number of commentators who point to the crucial role of religion in either generating and/or perpetuating the conflict. ${ }^{25}$ For example, Bruce, ${ }^{26}$ one of the earlier and leading proponents of this position, has emphasised the importance of religion, especially Protestant fundamentalism, in informing communal identities and thus both generating and perpetuating sectarian divisions within society. As Bruce put it: 'The Northern Ireland conflict is a religious conflict. ${ }^{, 27}$ More recent research provides some further support to this interpretation, or the continuing importance of religion in contributing to the conflict via its social and political significance. According to this perspective, not only does religion continue to be an essential component in the construction of identity within both communities - Protestant and Catholic - but it also remains a key factor in 
constituting as well as maintaining social divisions. As Mitchell, in exemplifying this position, argues: 'Religion plays an important role in constituting social divisions in Northern Ireland, rather than simply marking them out... As such, religion is an essential part of identification processes in contemporary Northern Ireland and it is at least as much about the social as about the spiritual'. ${ }^{28}$ In fact, some scholars go so far as to suggest that since the ratification of the Agreement, religious identity and practices have now moved centre stage as the key factor in both maintaining and perpetuating sectarian division within this society. ${ }^{29}$

More recent research, however, points to the intersection of religion and ethnicity in both generating and/or ameliorating communal division and conflict within this society. Rejecting either the assumed irrelevance or subordinate position of religion, proponents of this perspective suggest that not only is religious identity and ethnic identity closely intertwined in Northern Ireland, but both religious identity and ethnicity can exert an independent effect on communal division. ${ }^{30}$ However, as a number of scholars have noted, the relative importance attached to each identity - or the extent to which ethnicity and religion are 'thick' or 'thin' - can vary between groups as well as across social contexts. ${ }^{31}$ In other words, the relationship between religion and ethnicity is not clear-cut. While religion can, in some cases, dampen the effect of ethnicity and, thereby, assume salience in terms of communal unity or division, in other situations, it can help to reinforce and enhance the salience of ethnicity by identifying the 'other', or those outside the ethnic group. Mitchell's study of the effect of religion and ethnicity on working-class loyalists demonstrates that not only can religion be used by individuals for ethnic ends, such as a justification for the use of violence in those cases when religion and ethnicity come in conflict, but religion can also have a transformative effect or, in this case, overriding opposing ethnic lineages in the attempt to forge a unifying community of faith. ${ }^{32}$ Mitchell, in summarising the influence of both religious and ethnicity, writes: 'Religious ideas push and pull against ethnic ideas in the lives of individuals. It is rarely as straightforward as one causing the other. The tendency of religion to flux, fuse and sometimes jar demonstrates a lack of dominance of one element over the other.' 33

In summary, the role of both religion and ethnonationalism in relation to the conflict in Northern Ireland remains a contested and complex issue. While some 
scholars stress the primacy of ethnonationalism, others point to the crucial role of religion as a key mechanism for both generating and resolving conflict within this society. Still others, point to the independent effect of both religion and ethnic identity on communal cohesion and division within this society. It is with these considerations in mind that we now turn to an investigation of the net influence of religion and ethnonationalism on attitudes toward amnesty. A key focus of our investigation is to assess empirically the degree to which both ethnicity and religion may be considered a key determinant of views.

\section{DATA AND METHODS}

The data used in the analysis are from the 2011 Northern Ireland Social and Political Attitudes Survey. Conducted between April and August 2011, the survey is based on a multistage random sample and is representative of the adult population. Using a questionnaire design, it is based on personal interviews involving 1,500 respondents aged 18 years or older, with a response rate of 59 per cent. Given our main focus of interest - attitudes towards amnesty both within and between the two main religious communities - only individuals who identified themselves explicitly as Protestant or Catholic are included in our analysis. This accounts for 1,280 individuals or 85 per cent of the total sample and 97 per cent who explicitly claimed a religious affiliation. Attitudes towards amnesty, our dependent variable of interest, was operationalised in terms of a single item measure, namely levels of support or opposition towards the granting of amnesty for those who carried out acts of violence during the conflict. The response categories were: strongly support, support, neither support/nor oppose, oppose, strongly oppose.

Religion, our first explanatory variable of interest, is operationalised in terms of a range of religious measures, included a variety of religious practices such as church membership, attendance and prayer, and indictors of ones belief in and about God (see Appendix Table A1). ${ }^{34}$ Previous, predominantly US-based, survey research on the relationship between religion and attitudes towards a range of moral views, including attitudes towards capital punishment and the use of more stringent sanctions for convicted criminals, suggest that each of these measures has an important, albeit divergent, influence on attitudes. ${ }^{35}$ Of these various religious measures, however, it is the rigidity of one's belief in and perceptions of God, and not religious practices or 
even biblical literalism, which emerges as the primary determinant of views. ${ }^{36}$ For example, while a range of studies demonstrated that holding a rigid, or a definite, belief is God is a significant positive predictor of having a retributive attitude regarding criminal punishment and the death penalty, ${ }^{37}$ others point to the consistently negative effect of perceptions of a gracious God in relation to such views. ${ }^{38}$

Ethnonationalism, our other primary explanatory variable of interest, was operationalised in terms of congruency in religious, national, and communal identity. ${ }^{39}$ As previous research has shown, although national identity and communal affiliation significantly overlap in both religious communities in Northern Ireland, they are by no means coterminous. ${ }^{40}$ For example, not all Protestants perceived themselves as British and/or adopt a Unionist label. Similarly, not all Catholics view themselves as Irish or chose a Nationalist label. In Northern Ireland, religious affiliation, national identity and communal affiliation, including territorial preferences, were intertwined in a complex way which not only provided the basis for the conflict but, until recently, also reinforced its violent and recurrent nature. ${ }^{41}$ To allow for this factor, ethnonationalism is operationalised in terms of congruency Protestants who perceive themselves as both British and Unionist and Catholics who are willing to see themselves as both Irish and Nationalist - in ethnonational selfidentification. As in recent survey research, whereas 46 per cent of Protestants were willing to choose both identities and regard themselves as British and unionists, 48 per cent of Catholics were willing to describe themselves as both Irish and Nationalist. ${ }^{42}$

In addition, we included a number of potentially confounding background control variables such as gender, marital status, age, educational attainment and, most notably, victimhood status, given its highly contested and problematic nature both in Northern Ireland and in other societies emerging from conflict. ${ }^{43}$ Alternative analysis which excluded self-perceptions of victimhood from the investigation demonstrated no substantive difference in finding. With the exception of age (coded in terms of years) all control variables were included as a series of dummy variables (coded 0 and 1) in the analyses.

The analysis proceeds in two stages. First, we use ordinary least squares analysis to consider the net effect of religious identity on attitudes towards amnesty. 
This shows significant differences in relation to this issue between the two religious communities. Secondly, we then investigate the net impact of a range of religious measures - religious practices, beliefs in and about God - and congruency in ethnonational identity on attitudes towards amnesty within the two communities. Given the skewed nature of our dependent variable within the two religious communities - the majority of which are opposed to amnesty - for the purposes of this investigation attitudes towards amnesty has been recoded to the following two categories: strongly oppose/oppose (coded 1) and neither support nor oppose/oppose/strongly oppose (coded 0), and is based on a logistic regression analysis. The figures in each equation are the parameter estimates, while the standard errors for each of the estimations are shown in parentheses. Finally, the 'odds ratio' statistic shows whether the impact of both the control and explanatory variables socio-demographic background and self-perceptions of victimhood, as well as the various religion measures and ethnonational identity - increases (score greater than 1) or decreases (score less than 1) the likelihood of adopting an oppositional stance in relation to amnesty.

\section{RELIGION, ETHNONATIONALISM AND ATTITUDES TOWARDS AMNESTY}

As a result of over thirty years of conflict, with just under 3,500 dead and over 50,000 injured, the vast majority of which were members of the civilian population, the question of how to come to terms with the legacy of Northern Ireland's violent past remains an extremely contentious and on-going issue. ${ }^{44}$ This is particularly the case when the question of how to deal with ex-combatants are considered. As noted earlier, not only was the early release of prisoners considered deeply offensive to the majority of individuals but this was particularly the case among Protestants who saw themselves as pawns in the inexorable pursuit of peace. In fact, some commentators go so far as to suggest that the early release of prisoners as well as ongoing revelations concerning the granting of a royal pardon to a number of ex-combatants, has become, by far, one of the most the most distasteful and divisive aspects of the Northern Ireland peace process. ${ }^{45}$ 
The data in Table 1 lends some further support to this view. Irrespective of whether the Catholic or Protestant population are considered, the vast majority of individuals - or just under two-thirds in this instance - remain opposed to the granting of amnesty to ex-combatants. For example, whereas around a quarter of individuals were strongly opposed to such an initiative, a further two fifths also expressed an oppositional view. By contrast, only a minority of individuals, or around a fifth in each case, either supported or were undecided in their attitudes. Moreover, the strength of support for such an initiative is extremely tepid at best; just three per cent strongly supported the granting of amnesty to ex-combatants as compared to 26 per cent who were strongly opposed to such an approach. As expected, however, there are some marked differences between the two main religious communities in relation to this issue, with Catholics being notably less oppositional in their opinion than Protestants. While just over half of all Catholics adopted a more retributive or negative stance in relation to the granting of amnesty for those who admitted to carrying out acts of violence during the conflict, the equivalent proportion among Protestants was markedly higher at 77 per cent.

\section{[Insert Table 1 about here]}

Table 2 lends further confirmation to these findings. Even when a range of socio-demographic control variables as well as self-perceptions of victimhood are included in a regression analysis, religious identity emerges as a strong and differential net predictor of attitudes towards amnesty. Catholics are significantly less likely to adopt an oppositional stance in relation to this issue than Protestants. This is not to suggest, however, that religious identity is the sole determinant of attitudes in this instance. Other noteworthy predictors, net of other factors, include the positive effect of gender (women being more likely to oppose such an initiative than men) and the negative effect of victimhood status (victims were significantly less likely to adopt an oppositional stance in relation to amnesty than non-victims).

\section{[Insert Table 2 about here]}

To what extent, however, does the influence of religion endure when the impact both of a range of religious measures as well as ethnonational identity is investigated separately within the two main religious communities? Moreover, as 
suggested earlier, of the various religious measures, is it one's belief in and about God, which is the primary factor in accounting for views? Table 3 investigates this question by focusing on the net impact of a range of religious measures (such as participation and beliefs in and about God) and ethnonational identity on attitudes towards amnesty within both the Catholic and Protestant communities. The results are clear. Irrespective of whether Catholics or Protestants are considered, both religion and ethnonational identity are key distinguishing predictors of opinions concerning amnesty. Of the various religious measures, however, it is one's beliefs in or about God and not religious practices that are the most consistent determinants of views.

\section{[Insert Table 3 about here]}

Focusing initially on the Catholic population, the results in Table 3 are clear. Both religion and ethnonationalism are significant net predictors of attitudes towards amnesty. Of the various religious measures, however, it is one's beliefs in and about God, and not religious practices, which emerge as the key distinguishing determinants of attitudes in this instance. More specifically, it is a definite belief in God, perceptions of an engaged God and biblical literalism which are primary predictors of views. For example, individuals who definitely believe in God and who believe that the Bible is the literal word of God are almost twice as likely - the odds ratio are 1.91 and 1.85, respectively - net of all other factors, to adopt an oppositional stance in relation to amnesty than those who do not.

A similar, albeit converse, pattern emerges when perceptions concerning God's level of engagement with the world are considered. Catholics who believed in an engaged God were significantly less likely to support this position than those who did not. Or to put it in a positive direction for ease of interpretation: Catholics who did not believe in an engaged God were 1.89 times more likely (the inverse of $\exp (\mathrm{B})$ or $1 / 0.53$ ) to be opposed to amnesty than those who did. Finally, when congruency in identity is considered the direction of effect is again negative. Catholics who were congruent in terms of their identity (that is, who perceived themselves as both Irish and Nationalist) were also significantly less likely, net of all other factors, to adopt an oppositional stance in relation to amnesty than those who were not. ${ }^{46}$ Thus, at least as far as the relationship between religion and ethnonational identity on attitudes towards amnesty among the Catholic population is considered, it is individuals who believe in 
an engaged God and are congruent in their identity who stand out as the most consistent and the least oppositional in their views.

This is not to suggest that these religious measures or the impact of congruency in ethnonational identity are the sole predictors of attitudes in this instance. Of the socio-demographic control variables, both gender and age were also a significant positive determinant of views. While females were almost twice as likely as males to oppose amnesty, older individuals were also notably more likely to do so than their younger counterparts. By contrast, unlike our previous analysis, selfperceptions of victimhood failed to emerge as a significant determinant of attitudes in this instance, a not unexpected finding given the suggested dominance of both religion and ethnonationalism as the primary source and motivator of communal division and conflict within this society. ${ }^{47}$

These patterns are partially replicated when the opinions of Protestants are considered. Again, both religion and ethnonationalism are significant net predictors of attitudes towards amnesty within the Protestant community. Of the various religious measures, however, it is both biblical literalism and a belief in an engaged God which emerge as the key distinguishing determinants of views. As in our previous analysis, while Protestants who believed that the Bible was the literal word of God were significantly more likely to endorse an oppositional stance in relation to amnesty, individuals who believed in an engaged God were notably less likely to do so. Again, religious practices - and, in this instance, also denominational differences - failed to emerge as a significant predictor of views. Contrary to our previous analysis, however, congruency in ethnonational identity in this instance has a significant positive effect on attitudes. Protestants who viewed themselves as both British and Unionist were over four times more likely - the odds ratio is 4.52 - to oppose amnesty than those who did not. Thus, at least as far as the Protestant population is considered, it is individuals who either believe that the Bible is the literal word of God or express traditional notions of identity (British-Unionist) who stand out as the most uniform but oppositional in their views.

What may explain the differing direction of effects of ethnonationalism between the two religious communities? Part of explanation we suggest may rest with the contested nature both of victimhood and combatant status within this society. As 
noted earlier, the question of how to come to terms with the legacy of Northern Ireland's violent past remains an extremely contentious and on-going concern. This is particularly the case when the issue of how to deal with ex-combatants are considered. For example, not only was the early release of prisoners - both Republican as well as Loyalist - considered deeply offensive to the majority of individuals but this was particularly so in the Protestant community who saw themselves as 'innocent victims' sacrificed to appease the demands of 'convicted terrorists'. In fact, more so than any other factor, it is this assumed moral equivalence in status between perpetrators of 'terrorist' activity and their 'innocent' victims which lies at the heart of Protestant disillusionment with the Northern Ireland peace process and has stymied the introduction of a range of initiatives - such as a truth and reconciliation commission to deal with the legacy of its violent past.

\section{CONCLUSION}

Traditionally, studies of ethnicity, ethno-nationalism and ethnic conflict have paid scant attention to religion, viewing it as either superfluous or marginal at best. Pointing instead to the primary impact of a range of other influences, such as economic deprivation and greed or the political organisations of minority groups and their desire for self-determination, proponents of this perspective highlight the role of economic and/or political factors as the primary determinant of ethnically-based conflict and intra-state violence. Research over the last few decades, however, calls into question this view. Stressing instead the emergence of religion as a global political force, advocates of this position point to the role of religion as the primary source of conflict based on ethnonationalist disputes. In fact, some scholars go so far as to suggest that such religiously-based conflicts have now become the most pervasive form of conflict and the most common justification for terrorism in the world today.

More recent research, however, rejects the singularity of both these approaches. Focusing instead on the combined impact of both religion and ethnicity on conflict, proponents of this perspective argue that not only are religion and ethnicity deeply intertwined, but a key factor in accounting for intra-state conflicts 
based on ethnic differences is both their religious and ethnic dimensions. In other words, it is the intersection and combination of these two factors - both religion and national identity - which are the two most dominant features in predicting the onset of ethnonational disputes, or conflicts based on ethnic differences, in the post-Cold War era. And, while both religion and ethnonationalism are considered to have an independent net effect on such intra-state conflicts, the degree to which either religion or ethnnonationalist aspirations is the primary motivator of conflict remains open to some dispute. While some analysts point to the dominance of ethnonationalism, others highlight the religious dimension.

The results of our investigation lend some further support to this dualistic view - namely the influence of both religion and ethnonationalism as a key determinant in explaining attitudes towards amnesty. Our arguments in support of this proposition are threefold. First, religious identification is a key distinguishing predictor of opinions concerning amnesty. Even when a range of background control variables are included in the analysis, Protestants are significantly more oppositional in their views than Catholics. Secondly, when the impact of both religion and ethnonationalism within the two communities is considered separately, both religion and ethnonationalism are significant net predictors of attitudes. Of these various religious measures, however, it is one's belief in and about God which emerges as the key distinguisher of views. As in previous research on attitudes towards a range of moral attitudes, including the death penalty, ${ }^{48}$ while both religious rigidity, or holding a definite belief is God, and a view that the Bible is the literal word of God, are significant positive predictors of expressing a retributive, or oppositional stance, regarding amnesty, perceptions of an engaged God is a significant negative predictor of such views. Thirdly, a similar pattern emerges when the influence of ethnonationalism is considered. While ethnonationalism, or congruency in religious, national and communal identity, is a significant positive determinant of opposition towards amnesty among Protestants, it is has a significant negative effect on such views within the Catholic community. Finally, it is important to note, the relationship between religion and ethnonationalism on attitudes towards amnesty also differs between the two communities. While perceptions of an engaged God and ethnonationalism are the most consistent negative determinants of opinion with regard to opposition to amnesty among Catholics, it is a belief in the Bible as the literal word 
of God and ethnonational identity which emerge as the most uniform positive predictors of such retributive views within the Protestant community.

Overall, our results point to the important role of both religion and ethnonational identity in determining attitudes toward transitional justice mechanisms in societies emerging from conflict. It is to a further investigation of this issue - the complex and differential impact of both religion and national identity - on attitudes towards a variety of transitional justice mechanisms, such as truth commissions, that future research should be directed. Where possible a range of other religious and ethnic measures, such as religious saliency and strength of ethnic conviction, should also be included in the analysis. Only via such an examination, can the complex and net impact of both religion and ethnonational identity on ethnic conflict - including how to deal with the legacy of its violent past - be comprehensively investigated and understood.

\section{ACKNOWLEDGEMENTS}

The authors would like to thank the anonymous reviewers for their constructive and helpful comments

\section{FUNDING}

The 2011 Northern Ireland Social and Political Attitudes Survey was collected by John D. Brewer and Bernadette C. Hayes and funded by the Leverhulme Trust under the Compromise After Conflict Programme, grant number F/00/152/AK. 


\section{NOTES}

1. Peter Wallensteen, Understanding Conflict Resolution. (London: Sage $3^{\text {rd }}$ Edition, 2012).

2. Rogers Brubaker and David D. Laitin, 'Ethnic and Nationalist Violence.' Annual Review of Sociology 24: 423-452 (1998); Jeffrey Dixon, 'What Causes Civil Wars? Integrating Quantitative Research Findings.’ International Studies Review 11(4): 707735 (2009); Matthias Basedau, Birte Pfeiffer and Johannes Vullers, 'Bad Religion? Religion, Collective Action, and the Onset of Armed Conflict in Developing Countries.' Journal of Conflict Resolution 1-30 (2014).

3. Paul Collier, Anke Hoeffler and Dominic Rohner, 'Beyond Greed and Grievance: Feasibility and Civil War.' Oxford Economic Papers 61: 1-27 (2009).

4. Joakim Kreutz, 'How and When Armed Conflicts End: Introducing the UCDP Conflict Termination Data Set.' Journal of Peace Research 47(2): 243-250 (2010).

5. Lotta Themner and Peter Wallensteen, 'Armed Conflicts, 1946-2013.' Journal of Peace Research 51(4): 541-554 (2014).

6. Karl Cordell and Stefan Wolff, 'The Study of Ethnic Conflict: An Introduction.' in Karl Cordell and Stefan Wolff (eds.), The Routledge Handbook of Ethnic Conflict (Abingdon: Routledge, $2^{\text {nd }}$ Edition, 2016), 1-12.

7. Jonathan Fox, An Introduction to Religion and Politics: Theory and Practice (London: Routledge, 2013); Jonathan Fox. Political Secularism, Religion and the States: A Time Series Analysis of Worldwide Data (Cambridge: Cambridge University Press, 2015); Joseph Ruane and Jennifer Todd, 'Ethnicity and Religion.' In Karl Cordell and Stefan Wolff (eds.), The Routledge Handbook of Ethnic Conflict. (Abingdon: Routledge, $2^{\text {nd }}$ Edition, 2016), 67-77.

8. Donald L. Horowitz, Ethnic Groups in Conflict (Berkeley, CA: University of California Press, 1985); Robert Ted Gurr, Why Men Rebel (Princeton, NJ: Princeton University Press, 1970); Robert Ted Gurr, Minorities at Risk: A Global View of Ethnopolitical Conflicts (Washington, DC: United States Institute of Peace Press, 1993); Paul Collier and Anke Hoeffler, 'Greed and Grievance in Civil War.' Oxford Economic Papers 56: 563-595 (2004).

9. Frances Stewart, 'Religion versus Ethnicity as a Source of Mobilisation: Are There Differences?' (University of Oxford: Centre for Research on Inequality, Human Security and Ethnicity, CRISE Working Paper No. 70, 2009); Rogers Brubaker, 
'Religious Dimensions of Political Conflict and Violence.' Sociological Theory 33(1): 1-19 (2015).

10. Karel Dobbelaere, 'Towards an Integrated Perspective of the Processes Related to the Descriptive Concept of Secularization.' Sociology of Religion 60(3): 229-247 (1999); Steve Bruce, God is Dead: Secularization in the West. (Oxford: Blackwell, 2002).

11. Jonathan Fox, Religion, Civilization, And Civil War: 1945 Through The New Millennium (Lanham, MD: Lexington Books, 2004); Jonathan Fox, 'Integrating Religion into International Relations Theory.' In Jeffrey Haynes (ed.), Routledge Handbook of Religion and Politics (London: Routledge, 2009) 273-292; Isak Svensson, 'Fighting with Faith: Religion and Conflict Resolution in Civil Wars.' Journal of Conflict Resolution 51(6): 930-949 (2007); Monica Duffy Toft, 'Getting Religion? The Puzzling Case of Islam and Civil War.' International Security 31(4): 97-131 (2007); Matthias Basedau, Birte Pfeiffer and Johannes Vullers, 'Bad Religion? Religion, Collective Action, and the Onset of Armed Conflict in Developing Countries.' Journal of Conflict Resolution 1-30 (2014).

12. Mark Juergensmeyer, Terror in the Mind of God: The Global Rise of Religious Violence (London: University of California Press, $3^{\text {rd }}$ Edition, 2003); Tanja Ellingsen. 'Towards a Revival of Religion and Religious Clashes.' Terrorism and Political Violence 17: 305-332, (2005); Jonathan Fox, 'Integrating Religion into International Relations Theory.’ In Jeffrey Haynes (ed.), Routledge Handbook of Religion and Politics (London: Routledge, 2009) 273-292; Monica Duffy Toft, Daniel Philpott and Timothy Samuel Shah, God's Century: Resurgent Religion and Global Politics (London: W.W. Norton \& Company, 2011).

13. Louise Mallinder, Amnesty, Human Rights and Political Transitions: Bridging the Peace and Justice Divide (Portland: Hart Publishing, 2008); Tricia D. Olsen, Leigh A. Payne and Andrew G. Reiter, Transitional Justice in Balance: Comparing Processes, Weighting Efficacy (Washington, DC: United States Institute of Peace Press, 2010).

14. John Paul Lederach, Building Peace: Sustainable Reconciliation in Divided Societies (Washington, DC: United States Institute of Peace Press, 1997); R. Scott Appleby, The Ambivalence of the Sacred (Oxford: Rowman and Littlefield, 2000); Monica Duffy Toft, Daniel Philpott and Timothy Samuel Shah, God's Century: Resurgent Religion and Global Politics (London: W.W. Norton \& Company, 2011); Atalia Omer, R. Scott Appleby and David Little, The Oxford Handbook of Religion, Conflict and Peacebuilding (Oxford: Oxford University Press, 2015). 
15. Megan Shore, Religion and Conflict Resolution: Christianity and South Africa's Truth and Reconciliation Commission (Surrey: Ashgate, 2009).

16. Prisoners were released on licence and, thus, subject to a number of conditions, such as their lack of support for paramilitary organisation and their non-engagement in terrorist activity. In total 447 prisoners were released - 194 loyalist, 241 republican, and 12 non-aligned - under the provisions of the Northern Ireland Agreement. The programme saw all prisoners released within two years and many released within the first six months. See John D. Brewer and Bernadette C. Hayes, 'Victimisation and Attitudes Towards Former Political Prisoners in Northern Ireland.' Terrorism and Political Violence 27(4): 741-761 (2014), for a comprehensive discussion of this issue.

17. See Patricia Lundy and Mark McGovern, 'A Trojan Horse? Unionism, Trust and Truth Telling in Northern Ireland.' The International Journal of Transitional Justice 2: 42-62 (2008); Cheryl Lawther, Truth, Denial and Transition: Northern Ireland and the Contested Past (Oxon: Routledge, 2014).

18. Established in June 2007, the Consultative Group on the Past, contained 31 recommendations as to how Northern Ireland could address the legacy of its violent past, the most controversial of which was the suggested $£ 12,000$ 'recognition' payment to be awarded to the nearest relative of each person who died in the Northern Ireland conflict. Many victims groups and particularly members of the Protestant community were outraged, arguing that such a payment would indicate a moral equivalence between those who committed violence and the 'innocents' who were simply victims of violence. Such was the public outcry that, to date, none of the report's recommendations have been acted upon (see Consultative Group on the Past, Report of the Consultative Group on the Past (Belfast: OFMDFM, 2009).

19. As part of their recommendations to deal with the legacy of Northern Ireland's violent past, both the Haass and the Stormont House Agreement as well as the derivative 2015 Northern Ireland (Stormont House Agreement) Bill, proposed the establishment of an Independent Commission on Information Retrieval (ICIR) in which those involved in Troubles-related deaths could provide information to the ICIR in return for 'limited immunity' - the information provided would be inadmissible in court - as opposed to a blanket amnesty. As the subsequently abandoned Northern Ireland (Stormont House Agreement) Bill (2015: 7) put it: 'The ICIR will be separate to the criminal justice system and information provided to it will not be admissible in court. The ICIR will not provide an amnesty: it is information as provided to the ICIR which is protected, not the individual (or the information if it is 
obtained by another means). No individual who provides information would be immune from prosecution if the required evidential test is satisfied.' See Richard Haass, An Agreement Among the Parties of the Northern Ireland Executive on Parades, Select Commemorations, and Related Protests; Flags and Emblems: and Contending With the Past. (Belfast: Northern Ireland Office, 2013); Stormont House Agreement (Belfast: Northern Ireland Office, 2014); Northern Ireland (Stormont House Agreement) Bill (Belfast: Northern Ireland Office, 2015);

20. Similar marked divisions also occurred with the passage of the Civil Service (Special Advisor's) Bill (SPAD) in 2013, which made it illegal for any member of the Northern Ireland Legislative Assembly (MLA) to employ as a special advisor (SPAD) an ex-prisoner. While members of the Protestant/unionist community welcomed the bill, many within the Catholic/nationalist side were outraged, arguing that it sought to introduce a hierarchy of both victimhood and impunity; distinguishing between 'innocent' victims and those who have been engaged in 'terrorist' activities. See John D. Brewer and Bernadette C. Hayes, 'Victimisation and Attitudes Towards Former Political Prisoners in Northern Ireland.' Terrorism and Political Violence 27(4): 741761 (2014) 745.

21. Tony Fahey, Bernadette C. Hayes and Richard Sinnott, Conflict and Consensus: A Study of Values and Attitudes in the Republic of Ireland and Northern Ireland (Leiden: Brill, 2006).

22. John McGarry and Brendan O' Leary, Explaining Northern Ireland (Oxford: Blackwell, 1995) 213.

23. Ibid, 855 .

24. In 1970, the leaders of the four main Churches in Northern Ireland Presbyterian, Methodist, Church of Ireland, and Roman Catholic - issued a joint statement stating that religion was not a cause or component of the conflict. See Oliver Rafferty, Catholicism in Ulster 1603-1983: An Interpretative History (London: Hurst Publications, 1994) 270.

25. Steve Bruce, God Save Ulster! The Religion and Politics of Paisleyism (Oxford: Clarendon, 1986); John D. Brewer and Gareth I. Higgins, Anti-Catholicism in Northern Ireland 1600-1998 (London: Macmillan, 1998); Claire Mitchell, Religion, Identity and Politics in Northern Ireland: Boundaries of Belonging and Belief (Aldershot: Ashgate, 2006); John D, Brewer, Gareth I. Higgins and Francis Teeney, Religion, Civil Society and Peace in Northern Ireland (Oxford: Oxford University Press, 2011) 
26. Steve Bruce. God Save Ulster!

27. Ibid, 249.

28. Claire Mitchell, 'Religious Change and Persistence.' In Colin Coulter and Michael Murray (eds.) Northern Ireland After the Troubles: A Society in Transition (Manchester: Manchester University Press, 2008) 150.

29. Siobhan Garrigan, The Real Peace Process: Worship, Politics and the End of Sectarianism (London: Equinox, 2010).

30. Joseph Ruane and Jennifer Todd, 'Ethnicity and Religion: Redefining the Research Agenda.' In Joseph Ruane and Jennifer Todd (eds.), Ethnicity and Religion: Intersections and Comparisons (Abingdon: Routledge, 2011) 1-8.

31. Robert D. Lowe and Orla Muldoon, 'Religious and Ethnonational Identification and Political Violence.' In Joseph Ruane and Jennifer Todd (eds.), Ethnicity and Religion: Intersections and Comparisons (Abingdon: Routledge, 2011) 71-84; Claire Mitchell, 'The Push and Pull Between Religion and Ethnicity: The Case of Loyalists in Northern Ireland.’ In Joseph Ruane and Jennifer Todd (eds.), Ethnicity and Religion: Intersections and Comparisons (Abingdon: Routledge, 2011) 53-70.

32. Claire Mitchell. 'The Push and Pull Between Religion and Ethnicity.'

33. Ibid. 66 .

34. Although additional bivariate analysis demonstrates that some of these religion measures are significantly associated with each, in no instance are the zero-order correlations greater than 0.41 , suggesting that multicollinearity is not a problem in this instance. The variance inflation factor (VIF) for each of the various analyses -2.39 or less in all instances - lends some further support to this finding.

35. James D. Unnever, Francis T. Cullen and Brandon K. Applegate, 'Turning the Other Cheek: Reassessing the Impact of Religion on Punitive Ideology.' Justice Quarterly 22(3): 304-339 (2005); Christopher T. Bader, Scott A. Desmond , F. Carson Menckwn and Bryon R. Johnson, 'Divine Justice: The Relationship Between Images of God and Attitudes Towards Criminal Punishment.' Criminal Justice Review. 35(1): 90-106 (2010).

36. Christopher T. Bader, Scott A. Desmond, F. Carson Menckwn and Bryon R. Johnson, 'Divine Justice: The Relationship Between Images of God and Attitudes Towards Criminal Punishment.’ Criminal Justice Review. 35(1): 90-106 (2010); James D. Unnever, John P. Bartkowski and Francis T. Cullen, 'God Imagery and 
Opposition to Abortion and Capital Punishment: A Partial Test of Religious Support for the Consistent Life Ethic.' Sociology of Religion 71(3): 307-322 (2010).

37. David T. Evans and Mike Adams, 'Salvation or Damnation? Religion and Correctional Ideology.' American Journal of Criminal Justice 28(1): 15-35 (2003);

Christopher T. Bader, Scott A. Desmond, F. Carson Menckwn and Bryon R. Johnson, 'Divine Justice: The Relationship Between Images of God and Attitudes Towards Criminal Punishment.' Criminal Justice Review. 35(1): 90-106 (2010).

38. James D. Unnever, Francis T. Cullen and Brandon K. Applegate, 'Turning the Other Cheek: Reassessing the Impact of Religion on Punitive Ideology.' Justice Quarterly 22(3): 304-339 (2005); James D. Unnever, John P. Bartkowski and Francis T. Cullen, 'God Imagery and Opposition to Abortion and Capital Punishment: A Partial Test of Religious Support for the Consistent Life Ethic.' Sociology of Religion 71(3): 307-322 (2010).

39. For the purposes of this investigation and in common with previous research in the area, national identity refers to identification with labels such as 'British' and 'Irish'. Following the work of John Coakley - 'National Identity in Northern Ireland: Stability or Change.' Nations and Nationalism 13(4): 573-597 (2007) - we refer to whether an individual identifies as being 'unionist' or 'nationalist' as communal identity, otherwise known as political identity in much of the literature.

40. John Coakley, 'National Identity in Northern Ireland: Stability or Change.' Nations and Nationalism 13(4): 573-597 (2007); Bernadette C. Hayes and Ian McAllister, Conflict to Peace: Politics and Society in Northern Ireland Over Half a Century (Manchester: Manchester University Press, 2013).

41. See John D Brewer, 'Northern Ireland: Religion, Religiosity and Politics in a Changing Society’. In Stephen Hunt (ed.), Handbook of Global Christianity (Leiden: Brill, 2015) 208-230.

42. Bernadette C. Hayes and John Nagle, 'Ethnonationalism and Attitudes Towards Gay and Lesbian Rights in Northern Ireland.' Nations and Nationalism 22(1): 20-41 (2016).

43. See John D. Brewer and Bernadette C. Hayes, 'Victimhood Status and Public Attitudes Towards Post-Conflict Agreements: Northern Ireland as a Case Study.' Political Studies 6: 69-84 (2013); See John D. Brewer and Bernadette C. Hayes, 'Victimhood and Attitudes Towards Dealing with the Legacy of a Violent Past: Northern Ireland as a Case Study.' British Journal of Politics and International Relations 17(3): 512-530 (2014). Note: For the two main religious groupings - 
Protestant and Catholics - this accounted for 26 per cent of the total sample, with selfperceptions of victimhood being shared - at 25 per cent and 27 per cent, respectively - almost equally between them.

44. Estimates of deaths due to the political violence vary. The figures presented here have been calculated using official Police Service of Northern Ireland (PSNI) estimates. See Bernadette C. Hayes and Ian McAllister, Conflict to Peace: Politics and Society in Northern Ireland Over Half a Century (Manchester: Manchester University Press, 2013).

45. See John D Brewer, David Mitchell and Gerard Leavey, Ex-Combatants, Religion and Peace in Northern Ireland. (London: Palgrave, 2013); John D. Brewer and Bernadette C. Hayes, 'Victimisation and Attitudes Towards Former Political Prisoners in Northern Ireland.’ Terrorism and Political Violence 27(4): 741-761 (2014).

46. Or, again, to put it another way and in a positive direction for ease of interpretation: Catholics who were incongruent in their identity was 1.56 times - the inverse of $\exp (\mathrm{B})$ or 1/0.64 - more likely to adopt an oppositional stance in relation to amnesty than those who were not.

47. Additional bivariate analysis looking at the relationship between selfperceptions of victimhood and congruency in ethnonational identity lends further support to this explanation. Irrespective of whether the Catholic or Protestant population was considered, individuals who were congruent in their ethnonational self-identification - Protestants who were willing to see themselves as both British and Unionist and Catholics who described themselves as both Irish and Nationalist were significantly more likely to perceive themselves as victims of the conflict than those you were not.

48. Christopher T. Bader, Scott A. Desmond, F. Carson Menckwn and Bryon R. Johnson, 'Divine Justice: The Relationship Between Images of God and Attitudes Towards Criminal Punishment.' Criminal Justice Review. 35(1): 90-106 (2010). 
John D. Brewer is Professor of Post Conflict Studies at the Senator George J.

Mitchell Institute for Global Peace, Security and Justice, Queen’s University Belfast, Northern Ireland.

Bernadette C. Hayes is Professor of Sociology and Director of the Institute for Conflict, Transition, and Peace Research, University of Aberdeen, Scotland. 
Table 1: Religious Identity and Attitudes Towards Amnesty

\begin{tabular}{lccc}
\hline & Catholic & $\begin{array}{c}\text { (Percentages) } \\
\text { Protestant }\end{array}$ & All \\
\hline & & & \\
Strong Support & 4.0 & 1.3 & 2.6 \\
Support & 23.7 & 7.4 & 15.1 \\
Neither Support nor Oppose & 20.3 & 14.4 & 17.2 \\
Oppose & 37.0 & 41.5 & 39.3 \\
Strongly Oppose & 15.0 & 35.5 & 25.8 \\
Total & 100.0 & 100.0 & 100.0 \\
(N) & $(552)$ & $(612)$ & $(1,164)$ \\
\hline
\end{tabular}

Question: Could you tell me how you feel about the following issues: 'An amnesty for those who admit to carrying out acts of violence during the troubles.'

Source: Northern Ireland Social and Political Attitudes Survey, 2011. 
Table 2: The Net Effect of Religious Identity on Attitudes Towards Amnesty

\begin{tabular}{lcc}
\hline & \multicolumn{2}{c}{ Regression Coefficients (OLS) } \\
& $\mathrm{b}$ & Beta \\
\hline Socio-Demographic Background: & & .10 \\
Female & $.05^{* *}$ & -.01 \\
Married & -.01 & .04 \\
Age (years) & .01 & \\
Education: & --- & --- \\
$\quad$ Tertiary & .01 & .01 \\
$\quad$ Secondary & .01 & .02 \\
No qualification & $-.04^{*}$ & -.06 \\
Victimhood status (victim) & & \\
& & -.31 \\
Religious Identity: & $-.17^{* *}$ & \\
Catholic & & \\
Constant & $.702^{* *}$ & \\
R-squared & .110 & \\
(N) & $(1,164)$ & \\
\hline
\end{tabular}

Notes: Attitudes towards amnesty are coded from 0 (most supportive) to 1 (most opposed); *, significant at the 0.05 level; ${ }^{* *}$, significant at the 0.01 level; ${ }^{\text {a }}$, missing category of comparison.

Source: Northern Ireland Social and Political Attitudes Survey, 2011 
Table 3: The Net Effect of Religion and Ethnonationalism on Opposition Towards Amnesty Among Catholics and Protestants

\begin{tabular}{|c|c|c|c|c|c|c|}
\hline & \multicolumn{6}{|c|}{ (Logistic Regression Coefficients) } \\
\hline & \multicolumn{3}{|c|}{ Catholics } & \multicolumn{3}{|c|}{$\underline{\text { Protestants }}$} \\
\hline & Estimate & $(\mathrm{SE})$ & $\begin{array}{l}\text { Odds } \\
\text { Ratio }\end{array}$ & Estimate & (SE) & $\begin{array}{l}\text { Odds } \\
\text { Ratio }\end{array}$ \\
\hline \multicolumn{7}{|c|}{ Socio-Demographic Background: } \\
\hline Female & $0.67 * *$ & $(0.21)$ & 1.95 & 0.28 & $(0.23)$ & 1.33 \\
\hline Married & -0.09 & $(0.21)$ & 0.92 & 0.42 & $(0.24)$ & 1.55 \\
\hline Age (years) & $0.02 *$ & $(0.01)$ & 1.02 & -0.01 & $(0.01)$ & 0.99 \\
\hline \multicolumn{7}{|l|}{ Education: } \\
\hline Tertiary $^{\mathrm{a}}$ & --- & --- & --- & --- & --- & --- \\
\hline Secondary & -0.28 & $(0.29)$ & 0.76 & -0.13 & $(0.33)$ & 0.88 \\
\hline No qualification & -0.53 & $(0.36)$ & 0.59 & 0.27 & $(0.42)$ & 1.31 \\
\hline Victimhood status (victim) & -0.43 & $(0.22)$ & 0.65 & -0.31 & $(0.26)$ & 0.73 \\
\hline \multicolumn{7}{|l|}{ Religious Measures: } \\
\hline \multicolumn{7}{|l|}{ Denomination } \\
\hline Presbyterian $^{\mathrm{a}}$ & --- & --- & --- & --- & --- & --- \\
\hline Anglican & --- & --- & --- & -0.25 & $(0.27)$ & 0.78 \\
\hline Other Protestant & --- & --- & --- & -0.49 & $(0.29)$ & 0.61 \\
\hline \multicolumn{7}{|l|}{ Religious Practices } \\
\hline Church attendance (monthly) & 0.42 & $(0.34)$ & 1.52 & -0.45 & $(0.37)$ & 0.64 \\
\hline Pray (weekly) & -0.22 & $(0.25)$ & 0.80 & -0.14 & $(0.30)$ & 0.87 \\
\hline \multicolumn{7}{|l|}{ Beliefs In/About God } \\
\hline Believe (definitely) & $0.65^{* *}$ & $(0.23)$ & 1.91 & 0.24 & $(0.30)$ & 1.28 \\
\hline Engaged God & $-0.63 *$ & $(0.25)$ & 0.53 & $-0.67 *$ & $(0.30)$ & 0.51 \\
\hline Bible (Literal word of God) & $0.61 *$ & $(0.28)$ & 1.85 & $0.67 *$ & $(0.29)$ & 1.96 \\
\hline \multirow{2}{*}{$\begin{array}{l}\text { Ethnonationalism: } \\
\text { Irish-Nationalist/British- } \\
\text { Unionist }\end{array}$} & & & & & & \\
\hline & $-0.46^{*}$ & $(0.20)$ & 0.64 & $1.51^{* *}$ & $(0.26)$ & 4.52 \\
\hline Constant & $-0.936 *$ & & & & $1.595 * *$ & \\
\hline Nagelkerke R-square & .140 & & & & .191 & \\
\hline$(\mathrm{N})$ & (481) & & & & (543) & \\
\hline
\end{tabular}

Notes: Attitudes towards amnesty are coded 1 (opposed) and 0 (other); Standard errors (SE) are in parentheses; *, significant at the 0.05 level; ${ }^{* *}$, significant at the 0.01 level; a , missing category of comparison.

Source: Northern Ireland Social and Political Attitudes Survey, 2011 
Table A1: Measures

\begin{tabular}{|c|c|c|}
\hline Variable & Question & Response Categories \\
\hline $\begin{array}{l}\text { Attitudes Towards } \\
\text { Amnesty }\end{array}$ & $\begin{array}{l}\text { Could you tell me how you feel } \\
\text { about the following issues: An } \\
\text { amnesty for those who admit to } \\
\text { carrying out acts of violence } \\
\text { during the troubles }\end{array}$ & $\begin{array}{l}\text { Strongly support; support; neither support } \\
\text { nor oppose; oppose; strongly oppose. }\end{array}$ \\
\hline \multicolumn{3}{|c|}{ Religious Identity and Practices } \\
\hline Identity & $\begin{array}{l}\text { Do you regard yourself as } \\
\text { belonging to any particular } \\
\text { religion? If yes, which? }\end{array}$ & \\
\hline Church attendance & $\begin{array}{l}\text { Apart from special occasions } \\
\text { such as weddings, funerals, } \\
\text { baptisms and so on, how often } \\
\text { nowadays do you attend services } \\
\text { or meetings connected with your } \\
\text { religion? }\end{array}$ & $\begin{array}{l}8 \text { point scale ranging from } 1 \text { for never to } 8 \\
\text { for several times a week }\end{array}$ \\
\hline Pray & About how often do you pray? & $\begin{array}{l}11 \text { point scale ranging from } 1 \text { for never to } \\
11 \text { for several times a day }\end{array}$ \\
\hline \multicolumn{3}{|c|}{ One's Beliefs In and About God: } \\
\hline Belief in God & $\begin{array}{l}\text { Which statement comes closest } \\
\text { to expressing what you believe } \\
\text { about God? }\end{array}$ & $\begin{array}{l}\text { I don't believe in God; I don't know } \\
\text { whether there is a God and I don't believe } \\
\text { that there is a way to find out; I don't } \\
\text { believe in a personal God, but I do believe } \\
\text { in a Higher Power of some kind; I find } \\
\text { myself believing in God some of the time, } \\
\text { but not at others; While I have doubts, I do } \\
\text { feel that I do believe in God; I know God } \\
\text { really exists and I have no doubts about it }\end{array}$ \\
\hline Engaged God & $\begin{array}{l}\text { There is a God who concerns } \\
\text { Himself with every human being } \\
\text { personally }\end{array}$ & $\begin{array}{l}\text { Strongly agree; agree; neither agree nor } \\
\text { disagree; disagree; strongly disagree. }\end{array}$ \\
\hline Biblical literalism & $\begin{array}{l}\text { Which of these statements } \\
\text { comes closest to describing your } \\
\text { feelings about the Bible? }\end{array}$ & $\begin{array}{l}\text { The Bible is the actual word of God and is } \\
\text { to be taken literally, word for word; The } \\
\text { Bible is the inspired word of God but not } \\
\text { everything should be taken literally, word } \\
\text { for word; The Bible is an ancient book of } \\
\text { fables, legends, history and moral precepts } \\
\text { recorded by humankind; This does not } \\
\text { apply to me. }\end{array}$ \\
\hline \multicolumn{3}{|l|}{ Ethnonationalism: } \\
\hline National Identity & $\begin{array}{l}\text { Which of these best describes } \\
\text { the way you usually think of } \\
\text { yourself? }\end{array}$ & British, Irish, Ulster, Northern Irish, Other. \\
\hline Communal Identity & $\begin{array}{l}\text { Generally speaking, do you } \\
\text { think of yourself as a unionist, a } \\
\text { nationalist, or neither }\end{array}$ & Unionist, Nationalist, Neither \\
\hline
\end{tabular}

Source: Northern Ireland Social and Political Attitudes Survey, 2011 